\title{
EVALUATION OF ANTIBODIES PRODUCTION AGAINST BORRELIA BURGDORFERI IN CATTLE SUBMITTED TO RBM86 PROTEIN BOOPHILUS MICROPLUS TICK IMMUNIZATION AND ASSOCIATED CHALLENGES INFLUENCE
}

\author{
Márcia Mayumi Ishikawa ${ }^{1 *}$; Adivaldo Henrique Fonseca ${ }^{2}$, Natalino Hajime Yoshinari³ ${ }^{3}$ Ana Luiza Alves Rosa Osório ${ }^{1}$ \\ ${ }^{1}$ Mestrado Ciência Animal, Universidade Federal de Mato Grosso do Sul, Campo Grande, MS, Brasil. ${ }^{2}$ Universidade Federal \\ Rural do Rio de Janeiro, Rio de Janeiro, RJ, Brasil; ${ }^{3}$ Universidade de São Paulo, São Paulo, SP, Brasil.
}

\begin{abstract}
This paper corresponds to an "extended abstract" selected for oral presentation in the $22^{\text {nd }}$ Brazilian Congress of Microbiology, held in Florianópolis, SC, Brazil, in November 17-20, 2003
\end{abstract}

\begin{abstract}
IgG antibodies production against Borrelia burgdorferi in immunized cattle with $\mathrm{rBm} 86$ protein from Boophilus microplus was evaluated as well as the influence of the association between immunizations and stress through indirect ELISA test during one year. In the present study there was no influence of the isolated challenged used on the production of $\operatorname{IgG}$ antibodies against $B$. burgdorferi. The $\mathrm{rBm} 86 \mathrm{immunogen}$ did not cause significant oscillation in the production of IgG antibodies against $B$. burgdorferi capable to interfere in the serological results for Lyme Borreliosis in cattle. This study demonstrated the possibility of transitory changes in the production of antibodies after the association of vaccine stimuli and stress, emphasizing the necessity of serological studies combined with epidemiological and management data.
\end{abstract}

Key words: antibodies, Borrelia, cattle, tick.

\section{INTRODUCTION}

Lyme Borreliosis is an infectious illness, which involves humans, domestic and wild animals. Its diagnosis is a difficult procedure since its clinical manifestation is similar to other diseases and the immunodiagnosis needs specific standardization for each animal species and region under study $(1,3,7,8)$.

Bovines are domestic animals, which live very near humans, other domestic animals and some wild animals. The possible causes of natural and artificial stimuli to which these animals may have been submitted range from vaccine antigens to management stress and ectoparasites infestation (5).

The study of the profile of $B$. burgdorferi antibodies production in cattle in Brazil is necessary because studies carried out in the Southeast region have shown high antibodies titers and individual oscillations in asymptomatic animals, suggesting the existence of different stimuli for homologous immunological answer production in the detection of $\mathrm{IgG}$ antibodies standardized by Ishikawa et al. $(4,5,6,9,10)$.

This study aimed to evaluate the influence of some stimuli which could be associated and cause oscillation in the profile of the production of antibodies against $B$. burgdorferi utilizing the standardized ELISA test and therefore lead to interpretation mistakes in the survey studies according to the used sampling.

\section{MATERIALS AND METHODS}

Fifteen crossbreed dairy adult bovines kept in field at EMBRAPA - Animal Sanity, Seropédica county were immunized with $\mathrm{rBm} 86$ protein of $B$. microplus tick per intramuscular via in a total of 4 doses during one year. All the animals were vaccined according to the manufacturer recommendations. Samples of blood serum were collected after each challenge. They were stored, frozen at $-20^{\circ} \mathrm{C}$ and later submitted to the ELISA test in order to investigate IgG antibodies against B. burgdorferi.

*Corresponding author. Mailing address: Mestrado Ciência Animal, Universidade Federal de Mato Grosso do Sul. Av. Filinto Muller, 2443, Vila Ipiranga. 79070-900, Campo Grande, MS, Brasil. Tel.: (+5567) 345-3645. E-mail: marcia@nin.ufms.br 
Two bovines previously immunized in another experiment in which Ishikawa et al. (5) standardized the ELISA test were utilized to evaluate the vaccine stimuli in association with the previous immunization with hot inactivated B. burgdorferi and also with stress stimuli due to the management used in the biotery where the animals were kept during all the experiments. In this case the castration stress was evaluated.

One of the bovines mentioned was the inoculated (590), male, crossbreed dairy, previously immunized with hot inactivated B. burgdorferi, concentrated $1 \mathrm{mg} / 12 \mathrm{Kg}$ in 3 subcutaneous doses, in 15 spaced days. The other one was the control (591), male, crossbreed dairy, which received 3 subcutaneous doses of sterile PBS. These animals were immunized with $\mathrm{rBm} 86$ protein of B. microplus tick like the 15 animals kept in field and also received a fifth dose to confirm the results since the animals were castrated and submitted to intense stress.

The immunization obtained for the $\mathrm{rBm} 86$ protein of $B$. microplus tick was evaluated through an anti-rBm86 protein kit which uses gold probes marked with protein A.

\section{RESULTS}

The results obtained in the indirect ELISA test to investigate $\mathrm{IgG}$ antibodies against $B$. burgdorferi are demonstrated in Figs. 1 and 2 containing the respective vaccine doses dates and days of castration.

The results of the $\mathrm{rBm} 86$ protein of $B$. microplus tick immunization obtained with the anti-rBm86 Kit are shown in Tables 1 and 2.

Figure 1. Profile of $\operatorname{IgG}$ antibodies production anti B. burgdorferi in the inoculated (590) and control (591) bovines after rBm86 protein of $B$. microplus.tick vaccine.

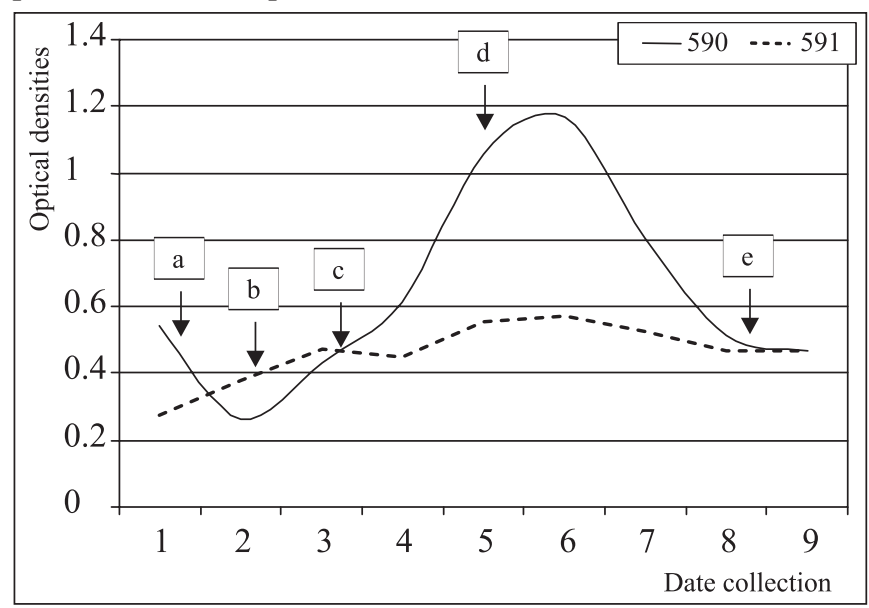

$a=1^{\text {st }} \operatorname{dose}(06 / 06 / 97) ; b=2^{\text {nd }} \operatorname{dose}(07 / 04 / 97)$;

$\mathrm{c}=3^{\text {rd }}$ dose and castration $(07 / 25 / 97)$;

$d=4^{\text {th }} \operatorname{dose}(12 / 04 / 97) e=5^{\text {th }}$ dose $(02 / 25 / 99)$.
Table 1. Results of anti rBm86 kit tests in the inoculated (590) and control (591) bovines.

\begin{tabular}{cc}
\hline Animal / Dose Number & Results \\
\hline $5901^{\text {st }}$ dose & ---- \\
$5902^{\text {nd }}$ dose & ---- \\
$5903^{\text {rd }}$ dose & +++-- \\
$5904^{\text {th }}$ dose & ++-- \\
$5905^{\text {th }}$ dose & +++++ \\
$5906^{\text {th }}$ collection & +++++ \\
$5911^{\text {st }}$ dose & ---- \\
$5912^{\text {nd }}$ dose & +++-- \\
$5913^{\text {rd }}$ dose & +++++ \\
$5914^{\text {th }}$ dose & +++++ \\
$5915^{\text {th }}$ dose & +++++ \\
$5916^{\text {th }}$ collection & +++++ \\
\hline
\end{tabular}

$+=$ Powerless reaction; $++=$ Medium reaction;

$+++=$ Good reaction; $++++=$ Powerful reaction;

$+++++=$ Excellent reaction.

Table 2. Results of the anti rBm86 kit tests in bovines 122, $140 \mathrm{e}$ 165 kept in field.

\begin{tabular}{cc}
\hline Animal / Dose Number & Results \\
\hline $1221^{\text {st }}$ dose & ---- \\
$1222^{\text {nd }}$ dose & ++++- \\
$1223^{\text {rd }}$ dose & ++++- \\
$1224^{\text {th }}$ dose & ++++ \\
$1401^{\text {st }}$ dose & ++-- \\
$1402^{\text {nd }}$ dose & +++- \\
$1403^{\text {rd }}$ dose & +++++ \\
$1404^{\text {th }}$ dose & ++++- \\
$1405^{\text {th }}$ collection & ++++- \\
$1651^{\text {st }}$ dose & ---- \\
$1652^{\text {nd }}$ dose & +--- \\
$1653^{\text {rd }}$ dose & +++-- \\
$16554^{\text {th }}$ dose & +++- \\
$1655^{\text {th }}$ collection & +++++ \\
\hline
\end{tabular}

$+=$ Powerless reaction; $++=$ Medium reaction;

$+++=$ Good reaction; $++++=$ Powerful reaction;

$+++++=$ Excellent reaction.

\section{DISCUSSION}

Lyme Borreliosis is classically transmitted through the bite of infected tick $(2,8)$ and thus stimuli deriving from this ectoparasite could be related to the stimuli produced by the causative agent of Borreliosis and detected by the diagnostic tests as being the same. In Brazil, the B. microplus tick constitutes the bovines tick with economic and sanity importance. GAVAC vaccine was evaluated and utilized in this tick's control programs, what constituted one more stimuli to 
Figure 2. Profile of $\mathrm{IgG}$ antibodies production against $B$. burgdorferi in bull, 28, 140 and 144 bovines kept in field.

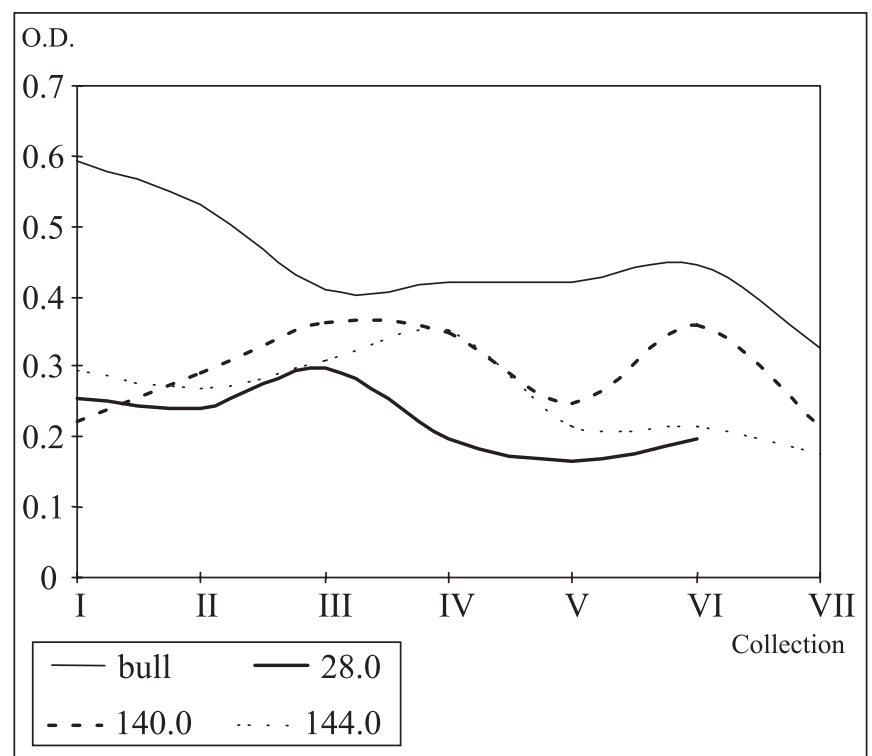

$\mathrm{a}=1^{\text {st }} \operatorname{dose}(12 / 06 / 96) ; \mathrm{b}=2^{\text {nd }} \operatorname{dose}(01 / 03 / 97)$;

$c=3^{\text {rd }}$ dose $(01 / 24 / 97) ; d=4^{\text {th }} \operatorname{dose}(06 / 06 / 97)$.

which bovines could be submitted and which was evaluated in this study.

There was no interference between IgG antibodies against B. burgdorferi production and the $\mathrm{rBm} 86$ protein of $B$. microplus tick immunization in the study of 15 animals (Fig. 1). The two bovines previously immunized with $B$. burgdorferi and sterile PBS showed a raise in the IgG antibodies against $B$. burgdorfer $i$ production after the third dose of $\mathrm{rBm} 86$ protein $B$. microplus tick, which occurred simultaneously with the castration and consequently the animals'stress.

After the total recovery of the animals, a fifth vaccine dose with $\mathrm{rBm} 86$ protein of $B$. microplus tick was conducted and in this reinforcement there was no raise in the production of IgG antibodies against $B$. burgdorferi. This fact suggested that there is no correlation between these two factors, what was confirmed in the results obtained with the 15 animals kept in field (Fig. 2). The necessity to study the associated challenges was observed, that is, more than one challenge at the same time.

The vaccine immunization of the animals utilized in this study was confirmed through the anti-rBm86 kit. This immunization was not sufficient to induce errors in the interpretation of the serological results for Lyme Borreliosis in cattle. Nevertheless, when associated with stress stimuli, there was modification in the profile of $\mathrm{IgG}$ antibodies production especially in the pre-immunized animal with B. burgdorferi, what showed the possibility of false positives due to stimuli association.

\section{ACKNOWLEDGEMENTS}

The authors would like acknowledge CNPq and Cargill S/A for support this study.

\section{RESUMO}

\section{Avaliação da produção de anticorpos anti Borrelia burgdorferi em bovinos submetidos à imunização com proteína rBm86 de carrapato Boophilus microplus $e$ influência dos desafios associados}

Avaliou-se a produção de anticorpos da classe Ig-G anti Borrelia burgdorferi em bovinos imunizados com proteína recombinante Bm86 de Boophilus microplus, assim como a influência de imunizações e estresse associados por meio do teste ELISA indireto no período de um ano. Não houve interferência na produção de anticorpos IgG anti B.burgdorferi pelos desafios utilizados isoladamente no presente estudo. O imunógeno rBm86 não causou oscilações significantes na produção de anticorpos IgG anti B. burgdorferi capazes de interferir nos resultados sorológicos para Borreliose de Lyme em bovinos. $\mathrm{O}$ estudo demonstrou a possibilidade de alterações transitórias na produção de anticorpos após estímulos vacinais e de estresse associados, ressaltando a necessidade de estudos sorológicos em conjunto a dados epidemiológicos e de manejo.

Palavras-chave: anticorpos, Borrelia, bovinos, carrapato.

\section{REFERENCES}

1. Barros, P.J.L. Contribuição ao conhecimento da doença de Lyme no Brasil. São Paulo, 1995, 83 pp. (Tese Mestrado. Faculdade de Medicina, Universidade de São Paulo).

2. Burgdorfer, W.; Barbour, A.G.; Hayes,S.F.; Lyme Disease: A Tickborne Spiroquetosis? Science, 216:1319, 1982

3. Burgess, E.C.; Gendron-Fitzpatrick, A.; Wright,W.O. Arthritis and Systemic Disease caused by Borrelia burgdorferi Infection in a Cow. JAVMA, 191:1468-1470, 1987.

4. Fonseca, A.H.; Ishikawa, M.M.; Soares, C.O.; Massard, C.L.; Yoshinari, N.H. Lyme Borreliosis serology in cattle and dogs in Brazil. Revista Universidade Rural, série Ciências da Vida, v.18, jun., 1996.

5. Ishikawa, M.M.; Fonseca, A.H.; Soares, C.O.; Massard, C.L.; Yoshinari, N.H. Padronização de Ensaio Imunoenzimático ELISA indireto para Pesquisa de Anticorpos da Classe IgG contra Borrelia burgdorferi em bovinos. Rev. Bras. Med. Vet., 19(04):166-168, 1997.

6. Ishikawa, M.M. Pesquisa de Anticorpos Anti Borrelia burgdorferi em Condições Experimentais e de Infecções Naturais em Bovinos. Rio de Janeiro, 2000. (Thesis, Instituto de Biologia, Universidade Federal Rural do Rio de Janeiro).

7. Parker, J.L.; White, K.W. Lyme Borreliosis in Cattle and Horses: a Review of the Literature. Cornell Vet., 82:253-274, 1982.

8. Steere, A.C.; Malawista, S.E.; Hardin, J.A.; Ruddy, S.; Askenase, P.W.; Andinan,W.A. Erythema Chronicum Migrans and Lyme Arthritis: the Enlarging Clinical Spectrum. Ann. Intern. Med., 86:685, 1977.

9. Soares, C.O.; Ishikawa, M.M.; Fonseca, A.H.; Yoshinari, N.H. Borrelioses, Agentes e Vetores. Pesq. Veterin. Brasil, 20(1):1-19, 2000.

10. Yoshinari, N.H.; Barros, P.J.L.; Bonoldi, V.L.M.; Ishikawa, M.M.; Battesti, D.M.B.; Pirana, S.; Fonseca, A.H.; Schumaker, T.T. Perfil da Borreliose de Lyme no Brasil. Rev. Hosp. Clin. Fac. Med. S. Paulo, 52(2):111-117, 1997. 